\title{
Early Enrollees and Peer Age Effect: First Evidence from INVALSI Data
}

\author{
Patrizia Ordine, Giuseppe Rose, Daniela Sposato \\ Correspondence: Patrizia Ordine, Department of Economics, Statistics and Finance, University of Calabria, Italy
}

\author{
Received: December 8, 2014 Accepted: January 9, 2015 Online Published: February 12, 2015 \\ doi:10.11114/jets.v3i2.602 \\ URL: http://dx.doi.org/10.11114/jets.v3i2.602
}

\begin{abstract}
This paper estimates peer age effect on educational outcomes of Italian pupils attending primary school by exploiting changes in enrollment rules over the last few years. The empirical procedure allows to understand if there is selection in classroom formation, arguing that in the absence of pupils sorting by early age at school entry, it is possible to estimate the "true" peer age effect. Results suggest that the proportion of youngest students "in advance" in the classroom has a positive impact on child's achievements measured by Normalized and Rasch test scores both in Reading and Mathematics. Additional empirical evidence shows that the effect on individual scores of sharing the classroom with pupils "in advance" differs by students' age group and it is higher for youngest pupils. Findings do not seem to be invalidated by "cheating" phenomena that may occur during the implementation and evaluation of tests.
\end{abstract}

Keywords: peer age effect, early enrollment, primary school, test scores, selection in classrooms formation

\section{Introduction}

Human capital production inevitably takes place in classrooms where pupils interact all together, generating what pedagogues call peer effects, sociologists contextual effects and economists social externalities (Vandenberghe, 2002).

The importance of peer effects occurs from the first years of schooling. As argued by Ladd (1990), children must foster positive peer groups early at school in order to become well-adjusted adolescents and adults. Furthermore, academic achievement and the often corresponding level of educational attainment tend to predict the average earnings an individual may secure over a lifetime. For this reason, isolating peer effects on academic achievement can make a significant contribution to the public debate over education reform.

Despite a growing literature on students' gender, ethnicity, and socioeconomic background peer effects, little literature exists on peer age effects. This research aims at giving a novel contribution to social interactions at class level by focusing on the impact of classmates' age on individual achievements, in the awareness that classrooms are formed by children with different age and that child's ability to accumulate human capital is affected by his/her own characteristics and by characteristics of his/her peers - including age. Specifically, we are interested in estimating the impact of classroom peer age composition on students' outcomes in the context of Italy, where rules on first enrollment at primary school permit to have classes composed by pupils aged between 65 and 80 months at school entry. As youngest children in the classroom may be more or less "ready" to learning, understanding how classroom age composition acts on students' outcomes becomes an important issue.

Classmates' age could operate through several channels. The presence of youngest pupils may exert a positive spillover on individual performance because teachers pay more attention when presenting lessons' topics. Second, the presence of youngest students could create a more disciplined school environment generating a positive spillover on the entire classroom. On top of that, since youngest children are those who have been sorted by their parents to enroll in advance, they could be particularly endowed with respect to other pupils in the class. In this case, the effect of peer age is due to a learning spillover between classmates. However it should also be considered that youngest pupils could experience more learning difficulties with a negative effect on their peers' educational outcomes.

Understanding the way through which interactions affect academic achievement is important for parents, educators, and policymakers, but, in practice, estimating their impact is a difficult task. Generally, empirical research which seeks to identify peer effects runs into two problems: omitted variable bias due to selection into a group and common teacher effects that influence all members of a group (i.e., correlated effects). The main barrier that must be overcome when estimating peer effects on student achievement is, however, the selection problem, as this issue reflects all unobserved characteristics that may confound peer effect estimate. Students could be sorted into peer groups for many reasons. First, parents send their children into schools based on their job locations or residential preferences - they live or work near 
the school - or on the basis of peers in the community as well as on the school quality. Second, classes within schools could not be formed randomly with respect to family background or other students' characteristics. For example, in primary schools, pupils from the same neighborhood or kindergarten could be put in the same classroom. Moreover, in the middle and upper secondary school, students could be systematically assigned to classes by abilities - that is by similar scores achieved in previous grades - in order to maximizeteaching effectiveness. Furthermore, parents could influence this process by choosing teachers' quality or by pushing for assignment in a specific classroom. Only if classrooms are formed randomly the peer effect can be estimated.

Starting from these considerations, we introduce an identification strategy generating estimates of peer age effects on educational outcomes that are credibly free of selection. Exploiting changes in Italian enrollment rules over the last few years, we are able to extract the causal impact of peer age group and to understand if the effect of classmates' age is due to selection in classrooms formation.

Thus, the question raised in this paper is: Does the age of peers affect child's cognitive achievement? Specifically, does the proportion of youngest students in the classroom affect individual performance?

To answer this questionwe use data from INVALSI (National Institute for the Educational Evaluation of Instruction and Training), focusing on assessment of the universe of pupils attending the 2nd and the 5th grade of primary school.

The paper is organized as follows. The next Section provides an overview of the previous studies on peer effects in education. Section 3 explains our insights and identification strategy, describes data source and variables used in the analysis, and discusses the empirical framework. Section 4 provides results of peer age effect on scores and presents some robustness checks. Section 5 concludes.

\section{Literature}

The estimation of peer effects in the classroom and at school has received intense attention in recent years. However, very little literature exists regarding peer age effect on educational outcomes.

Researchers have used various approaches to solve peer effects estimation issues. One common strategy to deal with the problem of correlated effects - i.e. the concern that measures of peer achievement may be biased by omitted unobservable characteristics that affect individual achievement - is to implement a fixed effect model. Several studies introduce school fixed effects to take into account non-random assignment (e.g., Ammermueller \& Pischke, 2009; Boucher, Bramoullé, Djebbari, \& Fortin, 2010; Duflo, Dupas, \& Kremer, 2008; McEwan, 2003; Ponzo \& Scoppa, 2014). Other researches exploit the availability of large administrative panel datasets to introduce student fixed effect (e.g., Carman \& Zhang, 2012; Hanushek, Kain, Markman, \& Rivkin, 2003; Lavy, Silva, \& Weinhardt, 2009), grade-within school and cohort-by-grade effects (e.g., Angrist \& Lang, 2004; Hanushek et al., 2003). Finally, some studies use teacher fixed effects to address common teacher influences (e.g., Burke \& Sass, 2013; Carman \& Zhang, 2012).

The majority of studies focusing on peer effects examine the effect of peer ability on students' outcomes. Several researches also provide evidence on race, gender and socioeconomic background peer effects whereas few contributions on peer age effects currently exist (e.g., Elder \& Lubotsky, 2009; Leuven \& Rønning, 2011; Sandgren \& Strøm, 2005; Boucher et al., 2010; Ponzo \& Scoppa, 2014).

\section{Method}

\subsection{Insights and Identification Strategy}

We investigate peer age effect on individual achievements measured by Normalized and Rasch test scores both in Reading and Mathematics by exploiting changes in enrollment rules in the Italian system. In particular, the Ministry of Education yearly publishes a law that sets the limit birth date for entry into first grade of primary school. As we use data on pupils attending both the 2nd and the 5th Grade in year 2012/2013, we exploit different rules for the corresponding 1st Grade enrollment that allow to implement a novel identification strategy. Our insight is the following (see Figure 1: Conceptual Framework of Identification Strategy). Students attending the 2nd Grade are enrolled in year 2011/2012. For this academic year, Italian regulations impose enrollment at school to pupils who are 6 years old by December 31st of the year when school starts (from now on, year t), and also permit enrollment to pupils who will be aged 6 by April 30th of year $t+1$ (Note 1). Students attending the 5th Grade are enrolled in year 2008/2009. For this academic year, Italian regulations impose enrollment at school to pupils who turn 6 six by August 31st of year $t$, and also permit enrollment to pupils who will be aged 6 by April 30th of year $t+1$ (Note 2). We can note that students in advance are those who turn six between January and April of year $t+1$ for the 2 nd Grade, while they are those who turn six between September of year $t$ and April of year $t+1$ for the 5 th Grade. 


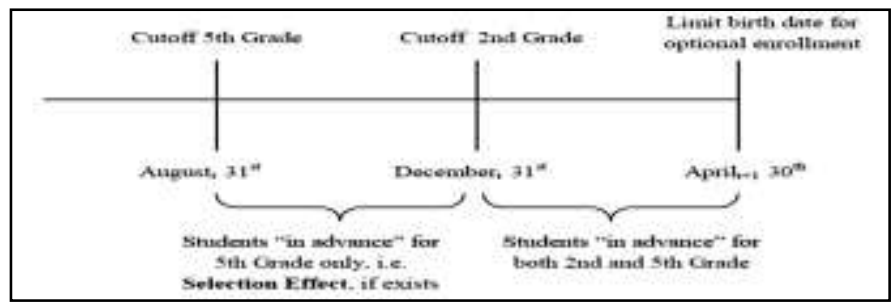

Figure 1. Conceptual Framework of Identification Strategy

In this framework, we can firstly investigate if the proportion of students in advance in the classroom both at the 2nd and at the 5th Grade affects individual performance. This is to say we are interested in the coefficient of the proportion of students who turn six between January and April of year $t+1$, which are the youngest students in advance in the class. Secondly, as a selection problem may arise in estimating classroom peer age effects on scores, we look at the proportion of students attending the 5th Grade who turn six between September and December of year t. By using this exogenous threshold we can test if early enrollees are actually randomly assigned to classrooms. Indeed, in the absence of any selection in classroom formation, the peer effect arising from students who turned six between September and December of year t, i.e. those who may be considered in advance only for the 5 th grade, should not be statistically different across grades.

\subsection{Sample, Measures and Covariates}

We use data from the INVALSI (National Institute for the Educational Evaluation and Training), which yearly carries out a survey on students' Reading and Mathematics competences through the National Service for the Evaluation of Education and Training (SNV). Assessment is currently realized at the 2nd and 5th Grades - primary school, 6th and 8th Grades - middle school, and Grade 10 - high school, and involves the universe of pupils attending respective grades.

In the present study, we focus on primary education analyzing data of both the 2 nd and the 5 th grade of the school year 2012/2013. We consider students of all Italian Provinces, except the Autonomous Provinces of Trento and Bolzano which have special enrollment rules for first school year. Our sample is representative and quite large, as it consists of about 500,000 pupils for the second school level and 480,000 pupils for the fifth school level. Both grades cover about 7,000 schools and 29,000 classrooms.

Data sets of the INVALSI contain a considerable number of variables that allow to control for student-level, school-level, family-level and geographic-level characteristics. To guarantee more reliable findings, we control for Sample Schools, in which the test is carried out in the presence of an external supervisor. Then, as robustness checks, we replicate results using as outcome variables the scores revised for cheating (Note 3).

For the purpose of this study, we generated some age measures: as we know the month and year of birth of the student, we first computed the age at school entry (in months); then we generated peer age variables at classroom level: proportion of students who turn six in each four months, from January-April of year $t$ to January-April of year $t+1$. We also consider the proportion of students who turn six in year $\mathrm{t}-\mathrm{n}$, identifying them as n-year delayed students.

As proxies for schooling outcomes, INVALSI provides both Normalized tests scores and Rasch test scores in Reading and Mathematics. We use both these measures. The first one represents the scores achieved by students taking the test. They are called "normalized" as computed in range 0 to 100 starting from "raw" scores. Rasch test scores are, instead, computed taking into account both the students' skills and the item difficulty, according to the Rasch model (Rasch, 1960).

In Table 1 we report the descriptive statistics of outcome variables. Normalized test scores in Reading and Mathematics range from 0 to 100 . We can note the mean in Reading is around 64 scores at the 2nd Grade while reaches around 77 scores at the 5th Grade, with an increase of 13 points. In Mathematics, instead, average test score is nearly constant across grades. All variables used in the analysis are described in Table 2.

Table 1. Descriptive Statistics of Outcome Variables

\begin{tabular}{|c|c|c|c|c|c|}
\hline & \multicolumn{5}{|c|}{ Grade 2} \\
\hline & Obs & Mean & Std. Dev. & Min & Max \\
\hline Normalized test score in reading & 489,631 & 64.402 & 17.831 & 0 & 100 \\
\hline Rasch test score in reading & 489,631 & 0.238 & 1.056 & -4.471 & 3.801 \\
\hline Normalized test score in mathematics & 491,702 & 60.685 & 21.571 & 0 & 100 \\
\hline \multirow[t]{3}{*}{ Rasch test score in mathematics } & 491,702 & 0.400 & 1.293 & -4.728 & 4.713 \\
\hline & \multicolumn{5}{|c|}{ Grade 5} \\
\hline & Obs & Mean & Std. Dev. & Min & Max \\
\hline Normalized test score in reading & 475,444 & 76.661 & 15.555 & 0 & 100 \\
\hline Rasch test score in reading & 475,444 & 0.176 & 1.119 & -5.427 & 4.120 \\
\hline Normalized test score in mathematics & 476,810 & 59.205 & 19.259 & 0 & 100 \\
\hline Rasch test score in mathematics & 476,810 & 0.242 & 1.067 & -5.231 & 4.778 \\
\hline
\end{tabular}




\subsection{The Empirical Framework}

To evaluate peer age effect on schooling achievements we start by using a pooled sample of pupils attending both 2nd and 5th grades and we estimate the following equation:

$$
\begin{aligned}
\mathrm{Y}_{\mathrm{ics}}=\alpha & +\beta \text { ClassAgeComposition }_{\mathrm{ics}}+\gamma \mathrm{StudC}_{\mathrm{ics}}+\delta \mathrm{SchoolC}_{\mathrm{ics}}+ \\
& +\eta \text { Parents }_{\mathrm{ics}}+\theta \text { GeographicC }_{\mathrm{ics}}+\phi \mathrm{Grade}_{\mathrm{ics}}+\varepsilon_{\mathrm{ics}}
\end{aligned}
$$

In eq. (1) $Y$ denotes individual performance, in either Reading or Mathematics, of student $i$ in the classroom $c$ in the school s; StudC, SchoolC, ParentsC, GeographicC are vectors of student, school, parents' socioeconomic background and geographic characteristics respectively - as defined in Table 2 - which affect the outcome variables; Grade5 is a dummy variable indicating if the student attends the 5 th grade, and $\varepsilon_{\text {ics }}$ is the individual error term.

ClassAgeComposition is a matrix of variables related to the age at school entry of pupils in the classroom, better identified as follows: i) Proportion of students who turn six in years t-n; ii) Proportion of students who turn six between January-April of year t; iii) Proportion of students who turn six between May-August of year $t$; iv) Proportion of students who turn six between September-December of year $t$; v) Proportion of students who turn six between January-April of year $\mathrm{t}+1$.

Our specific focus is on the proportion of students who turn six between January and April of year $t+1$. This variable represents those who are in advance in the classroom for both grades. In order to interpret the parameter associated to this variable as the peer age effect of early enrollees, we must be sure that they are randomly assigned to classrooms. We can handle this problem by using the insights and the identification strategy described in Section 3.1. We use a pooled sample of students attending both grades and we estimate the following equation:

$$
\begin{aligned}
& \mathrm{Y}_{\mathrm{ics}}=\alpha+\beta \text { ClassAgeComposition }_{\text {ics }}+\gamma \mathrm{StudC}_{\mathrm{ics}}+\delta \mathrm{SSchoolC}_{\mathrm{ics}}+\eta \text { ParentsC }_{\mathrm{ics}}+ \\
+ & \theta \mathrm{GeographicC}_{\mathrm{ics}}+\phi \text { Grade }_{\text {ics }}+\lambda\left(\text { Grade }^{*} \text { ClassAgeComposition }_{\mathrm{ics}}\right)+\psi_{\mathrm{cs}}+\varepsilon_{\mathrm{ics}}
\end{aligned}
$$

where we add to regressors in equation (1) the interaction vector Grade ${ }^{*}$ ClassAgeComposition $_{\text {ics }}$ and $\psi_{\text {cs }}$ which is the class level error term. We can test whether early enrollees follow assignment rules similar to those of regular ones by

\begin{tabular}{|c|c|c|c|}
\hline \multirow{3}{*}{\multicolumn{2}{|c|}{$\begin{array}{l}\text { OUTCOME VARIABLES: } \\
\text { Normalized Scores in Reading and Mathematics } \\
\text { Rasch Scores in Reading and Mathematics }\end{array}$}} & \multicolumn{2}{|l|}{ Description } \\
\hline & & \multirow{2}{*}{\multicolumn{2}{|c|}{ Continuous variable }} \\
\hline & & & \\
\hline \multicolumn{4}{|c|}{ COVARIATES: } \\
\hline \multirow[t]{7}{*}{$\begin{array}{l}\text { Student-level } \\
\text { variables }\end{array}$} & $\begin{array}{l}\text { Age at school entry } \\
\text { (in months) }\end{array}$ & $\begin{array}{l}\text { Discrete variable } \\
\text { (range } 65 \text { to } 116 \text { ) }\end{array}$ & - \\
\hline & Gender & Dummy variable & Male; Female \\
\hline & Country of birth & Dummy variable & Italy; Foreign Country \\
\hline & Pre-school attendance & Dummy variable & Daycare (yes/no); Kindergarten (yes/no) \\
\hline & $\begin{array}{l}\text { Father's/Mother's country } \\
\text { of birth }\end{array}$ & Dummy variable & Italy; Foreign Country \\
\hline & $\begin{array}{l}\text { Father's/Mother's } \\
\text { education }\end{array}$ & Dummy variable & $\begin{array}{l}\text { 'Low' if primary school certificate, lower secondary school certificate, } \\
\text { vocational secondary school diploma ( } 3 \text { years of study); 'Medium' if upper } \\
\text { secondary school diploma, another qualification higher than diploma; 'High' } \\
\text { if university degree or postgraduate qualification. }\end{array}$ \\
\hline & $\begin{array}{l}\text { Father's/Mother's } \\
\text { employment status }\end{array}$ & Dummy variable & $\begin{array}{l}\text { Unemployed; Homemaker; 'Low status' if laborer, services personnel, } \\
\text { member of cooperatives; 'Medium status' if self-employed worker (trader, } \\
\text { farmer, craftsman); Teacher, employee, military in career; Retired worker; } \\
\text { 'High status' if entrepreneur, landowner; Manager, university lecturer, } \\
\text { officer; Professional employee or freelancer. }\end{array}$ \\
\hline \multirow{3}{*}{$\begin{array}{l}\text { School-level } \\
\text { variables }\end{array}$} & $\begin{array}{l}\text { School size } \\
\text { (N of classrooms) }\end{array}$ & Discrete variable & - \\
\hline & Index of Sample school & Dummy variable & Sample school; no School sample \\
\hline & School weekly hours & Dummy variable & $\begin{array}{l}\text { Normal Time (Up to } 30 \text { hours at the } 2 \text { nd Grade }- \text { Up to } 39 \text { hours at the } 5 \text { th } \\
\text { Grade); Full Time ( } 40 \text { hours) }\end{array}$ \\
\hline \multirow[t]{5}{*}{$\begin{array}{l}\text { Classroom-level } \\
\text { variables }\end{array}$} & $\begin{array}{l}\text { Proportion of students } \\
\text { who turn six in years t-n }\end{array}$ & Continuous variable & - \\
\hline & $\begin{array}{l}\text { Proportion of students who } \\
\text { turn six between } \mathrm{Jan}_{\mathrm{t}}-\mathrm{Apr}_{\mathrm{t}}\end{array}$ & Continuous variable & - \\
\hline & $\begin{array}{l}\text { Proportion of students who } \\
\text { turn six between May } \text { Mug }_{t}\end{array}$ & Continuous variable & - \\
\hline & $\begin{array}{l}\text { Proportion of students who } \\
\text { turn six between Sept } t_{t}-\text { Dec }_{t}\end{array}$ & Continuous variable & - \\
\hline & $\begin{array}{l}\text { Proportion of students who } \\
\text { turn six between }\end{array}$ & Continuous variable & - \\
\hline $\begin{array}{l}\text { Geographic-level } \\
\text { variables }\end{array}$ & $\begin{array}{l}\mathrm{Jan}_{t+1}-\mathrm{Apr}_{\mathrm{t+1}} \\
\text { Province }\end{array}$ & Dummy variable & 101 Dummy variables for Italian Provinces \\
\hline
\end{tabular}
checking for the significance of the parameter - belonging to the parameters' vector $\lambda$ - associated with the variable indicating the proportion of students who turn six between September and December of year $t$ interacted with Grade5.

Table 2. Description of Variables 


\section{Results and Discussion}

\subsection{Estimating Peer Age Effect on Scores}

\subsubsection{Preliminary Findings}

With the purpose of estimating the impact of classroom peer age on educational outcomes, we start by considering a pooled sample of students attending both the 2nd and the 5th grade in Italian primary school. We control for all observed variables that are likely to affect the individual achievement. The estimated coefficients present the sign and the expected significance so that, for the sake of simplicity, we don't report all estimated parameters.

First of all we comment on individual age coefficients. Results from Table 3 show that student's age at school entry has a positive effect on both Reading and Mathematics scores: an older pupil performs better than a younger one. All coefficients are positive and statistically significant at the level of $1 \%$. The impact is higher in Mathematics than in Reading. These findings are consistent with Ordine, Rose, \& Sposato (2014) who found that the youngest students in the classrooms have lower performances in test scores.

Beside individual age, classroom peer age also affects educational achievements. Specifically, the presence of students who turn six between January and April of year $t+1$, seems to give rise to a positive spillover on pupil performance. This impact appears to be lower in Mathematics than in Reading.

Table 3. Pooled estimates of Classroom Peer Age Effect on Educational Outcomes

\begin{tabular}{|c|c|c|c|c|}
\hline & \multicolumn{2}{|c|}{$Y=$ Normalized test scores } & \multicolumn{2}{|c|}{$\mathrm{Y}=$ Rasch test scores } \\
\hline & Reading & Mathematics & Reading & Mathematics \\
\hline INDIVIDUAL AGE & & & & \\
\hline Student's Age at school entry (in months) & $0.240 * * *$ & $0.345 * * *$ & $0.016 * * *$ & $0.020 * * *$ \\
\hline CLASSROOM PEER AGE COMPOSITION & & & & \\
\hline Proportion of delayed students & $-7.856 * * *$ & $-9.224 * * *$ & $-0.497 * * *$ & $-0.475 * * *$ \\
\hline Proportion of students who turn six between $\mathrm{Jan}_{\mathrm{t}}-\mathrm{Apr}_{\mathrm{t}}$ & 0.263 & $0.931 * * *$ & 0.006 & $0.050 * * *$ \\
\hline Proportion of students who turn six between $\operatorname{Sept}_{\mathrm{t}}-\mathrm{Dec}_{\mathrm{t}}$ & $-0.906 * * *$ & $-1.665 * * *$ & $-0.059 * * *$ & $-0.097 * * *$ \\
\hline Proportion of students who turn six between $\mathrm{Jan}_{t+1}-\mathrm{Apr}_{\mathrm{t}+1}$ & $1.139 * * *$ & $0.845 * *$ & $0.105 * * *$ & $0.083 * * *$ \\
\hline Number of Obs & 582,813 & 583,615 & 582,813 & 583,615 \\
\hline
\end{tabular}

Notes: 1$) * \mathrm{p}<0.1 ; * * \mathrm{p}<0.05 ; * * * \mathrm{p}<0.01 .2)$ Coefficients are estimated with robust standard errors. 3) Estimates include student-level (individual characteristics and parents' background), school-level and geographic-level covariates; see Table 2 for details.

\subsubsection{Identification of Selection Effect and Unbiased Peer Age Effect}

In this Section we try to identify the potential Selection Effect, i.e. to verify if there is sorting in classroom formation by exploiting changes in Italian enrollment rules over the last few years, as described in Section 3.1. Estimates are provided in Table 4. We can first note that results on the individual age coefficients are consistent with our previous findings, i.e., pupils enrolled one year later have better score both in Reading and in Mathematics.

Turning to classroom peer age composition, coefficients associated to the proportion of students in advance in the classroom in both grades, consisting in those who turn six between January and April of year $t+1$, seem to provide evidence of a benefit for those in the same classroom. An increase of the proportion of youngest students in advance in the classroom determines a higher individual Normalized test score, on average, of 7.584 points in Reading and 8.999 points in Mathematics. These positive effects, which are robust at $1 \%$ significance level, are also found in regressions on Rasch test scores (see Table 4).

Table 4. Classroom Peer Age Effect and Identification of Selection Effect: 2nd and 5th Grade

\begin{tabular}{|c|c|c|c|c|}
\hline \multirow[b]{3}{*}{ INDIVIDUAI AGE } & \multicolumn{2}{|c|}{$Y=$ Normalized test scores } & \multicolumn{2}{|c|}{$\mathrm{Y}=$ Rasch test scores } \\
\hline & Reading & Mathematics & Reading & Mathematics \\
\hline & & & & \\
\hline Student's Age at school entry (in months) & $0.240 * * *$ & $0.345 * * *$ & $0.016 * * *$ & $0.020 * * *$ \\
\hline \multicolumn{5}{|l|}{ CLASSROOM PEER AGE COMPOSITION } \\
\hline Proportion of delayed students & $-7.896 * * *$ & $-10.776 * * *$ & $-0.334 * * *$ & $-0.571 * * *$ \\
\hline Proportion of students who turn six between $\mathrm{Jan}_{\mathrm{t}}-\mathrm{Apr}_{\mathrm{t}}$ & $-1.130 * * *$ & $-0.723 *$ & $-0.082 * * *$ & $-0.086^{* * *}$ \\
\hline Proportion of students who turn six between Sept $_{t}-$ Dec $_{t}$ & $-0.925 * * *$ & $-2.053 * * *$ & $-0.040 * *$ & -0.116 \\
\hline Proportion of students who turn six between $\mathrm{Jan}_{\mathrm{t}+1}-\mathrm{Apr}_{\mathrm{t}+1}$ & $7.584 * * *$ & $8.999 * * *$ & $0.443 * * *$ & $0.700 * * *$ \\
\hline Grade $5 *$ Proportion of delayed students & 1.126 & 5.583 & -0.113 & $0.398 * * *$ \\
\hline Grade $5 *$ Proportion of students who turn six between $\mathrm{Jan}_{\mathrm{t}}-\mathrm{Apr}_{\mathrm{t}}$ & $4.849 * *$ & $7.554 * *$ & $0.380 * *$ & $0.605 * * *$ \\
\hline Grade $5 *$ Proportion of students who turn six between $\mathrm{May}_{\mathrm{t}}-\mathrm{Aug}_{\mathrm{t}}$ & 1.864 & 4.023 & 0.193 & $0.316^{*}$ \\
\hline Grade $5 *$ Proportion of students who turn six between Sept $_{t}-$ Dec $_{t}$ & 2.058 & 4.096 & 0.164 & 0.367 \\
\hline Number of Obs & 582,813 & 583,615 & 582,813 & 583,615 \\
\hline
\end{tabular}


Notes: 1$) * \mathrm{p}<0.1 ; * * \mathrm{p}<0.05 ; * * * \mathrm{p}<0.01 .2)$ Coefficients are estimated with robust standard errors. 3) Estimates include student-level (individual characteristics and parents' background), school-level and geographic-level covariates; see Table 2 for details. Grade 5 *Proportion of students who turn six between $\mathrm{Jan}_{\mathrm{t}+1}-\mathrm{Apr}_{\mathrm{t}+1}$ excluded dummy variable.

As this effect could be biased by systematic assignment of students to classes by age at school entry, we verify if there is any selection bias by checking the significance of the proportion of students who turn six between September and December of year $t$ attending the 5th grade. Coefficients associated to this group of students are not statistically significant for both Reading and Mathematics test scores. This means that systematic assignment of children and teachers to classrooms does not seem to take place and to be relevant in determining the performance of Italian primary school pupils.

\subsubsection{Does Peer Age Effect differ by Students’ Age Group?}

If previous estimates provide a robust evidence of a positive spillover on individual performance in sharing the classroom with youngest students in advance, an interesting question remains open. The effect of the proportion of pupils in advance in the classroom on scores could differ by age group. For example, the impact could be higher for the youngest than for the oldest ones, or vice versa. In this Section we explore the impact of the proportion of students who turn six between January and April of year $t+1$ on test scores by students' age group. In particular, we run separate regressions by considering four age groups: i) students who turn six between January and April of year $t+1$, (age from 65 to 68 months at school entry); ii) students who turn six between September and December t (age from 69 to 72 months); iii) students who turn six between May and August t (age from 73 to 76 months); iv) students who turn six between January and April of year t (age from 77 to 80 months).

Table 5 presents findings of peer age effect on Normalized test scores and Table 6 reports results for Rasch test scores. Graphical illustrations of a decreasing effect with increasing age are provided in Figures 2 and 3 . The impact of the proportion of pupils who turn six between January and April of year $t+1$ on scores is higher for youngest students since the coefficient is decreasing in age.

Table 5. Classroom Peer Age Effect on Normalized Test Scores by Students' Age Group

\begin{tabular}{|c|c|c|c|c|}
\hline \multirow[b]{3}{*}{ CLASSROOM PEER AGE COMPOSITION } & \multicolumn{4}{|c|}{ Reading } \\
\hline & $\begin{array}{c}65 \leq \text { Age } \leq 68 \\
\text { (Students who } \\
\text { turn six between } \\
\left.\mathrm{Jan}_{\mathrm{t}+1}-\mathrm{Apr}_{\mathrm{t}+1}\right)\end{array}$ & $\begin{array}{c}69 \leq \text { Age } \leq 72 \\
\text { (Students who } \\
\text { turn six between } \\
\text { Sept }_{\mathrm{t}}-\mathrm{Dec}_{\mathrm{t}} \text { ) }\end{array}$ & $\begin{array}{c}73 \leq \text { Age } \leq 76 \\
(\text { Students who } \\
\text { turn six between } \\
\left.\text { May }_{\mathrm{t}}-\mathrm{Aug}_{\mathrm{t}}\right)\end{array}$ & $\begin{array}{c}77 \leq \text { Age } \leq 80 \\
\text { (Students who } \\
\text { turn six between } \\
\mathrm{Jan}_{\mathrm{t}}-\mathrm{Apr}_{\mathrm{t}} \text { ) } \\
\end{array}$ \\
\hline & $10.018 * * *$ & $10.090 * * *$ & $7.437 * * *$ & $5.179 * * *$ \\
\hline \multirow[t]{3}{*}{ Number of Obs } & 47,078 & 191,035 & 195,848 & 138,286 \\
\hline & \multicolumn{4}{|c|}{ Mathematics } \\
\hline & $\begin{array}{c}65 \leq \text { Age } \leq 68 \\
\text { (Students who } \\
\text { turn six between } \\
\left.\mathrm{Jan}_{\mathrm{t}+1}-\mathrm{Apr}_{\mathrm{t}+1}\right)\end{array}$ & $\begin{array}{c}69 \leq \text { Age } \leq 72 \\
\text { (Students who } \\
\text { turn six between } \\
\text { Sept }_{\mathrm{t}}-\mathrm{Dec}_{\mathrm{t}} \text { ) }\end{array}$ & $\begin{array}{c}73 \leq \text { Age } \leq 76 \\
\text { (Students who } \\
\text { turn six between } \\
\text { May }_{\mathrm{t}}-\text { Aug }_{\mathrm{t}} \text { ) }\end{array}$ & $\begin{array}{c}77 \leq \text { Age } \leq 80 \\
\text { (Students who } \\
\text { turn six between } \\
\text { Jan }_{\mathrm{t}}-\mathrm{Apr}_{\mathrm{t}} \text { ) }\end{array}$ \\
\hline $\begin{array}{l}\text { CLASSROOM PEER AGE COMPOSITION } \\
\text { Proportion of students who turn six between } \mathrm{Jan}_{\mathrm{t}+1}-\mathrm{Apr}_{\mathrm{t}+1}\end{array}$ & $14.731 * * *$ & $10.999 * * *$ & $6.979 * * *$ & $4.938 * * *$ \\
\hline Number of Obs & 47,027 & 191,318 & 196,001 & 138,586 \\
\hline
\end{tabular}

Notes: 1) $* \mathrm{p}<0.1 ; * * \mathrm{p}<0.05$; *** $\mathrm{p}<0.01 .2)$ Coefficients are estimated with robust standard errors. 3) Estimates include student-level (individual characteristics and parents' background), school-level, geographic-level and other classroom peer age composition covariates; see Table 2 for details.

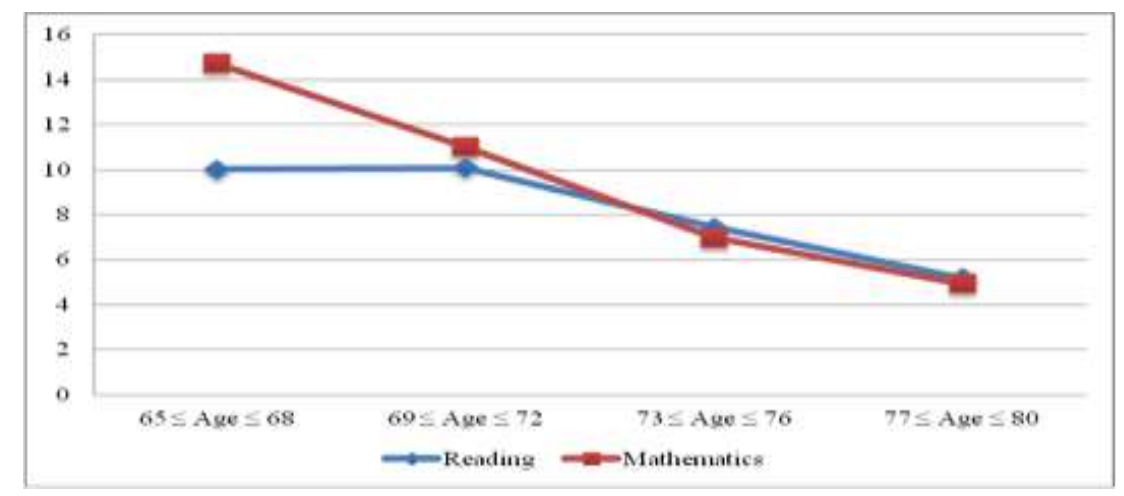


Figure 2. Effect of the Proportion of students who turn six between January $t+1$ and April $t+1$ on Normalized test scores by Students' Age Group. Notes: The horizontal axis reports four students' age groups. The first one identifies pupils who turn six between January $\mathrm{t}+1$ and April $\mathrm{t}+1$, who are youngest pupils in the classroom (age from 65 to 68 months at school entry). Others groups include students who turn six in the others four months of year t, identifying an increasing age. The vertical axis reports the effects of the Proportion of students who turn six between January $t+1$ and April $t+1$, on Normalized test scores in Reading and Mathematics.

Table 6. Classroom Peer Age Effect on Rasch Test Scores by Students' Age Group

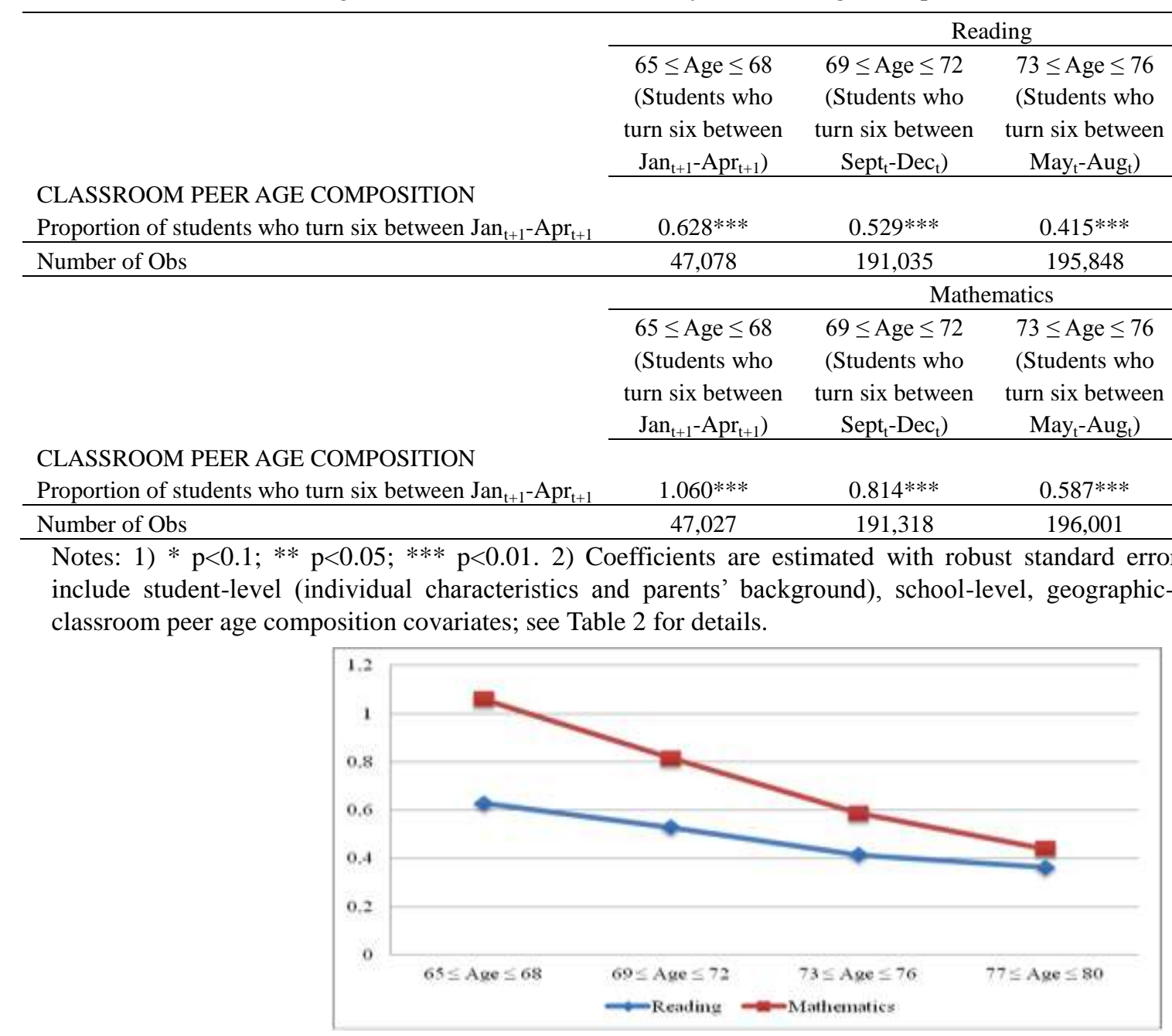

Figure 3. Effect of the Proportion of students who turn six between January $t+1$ and April $t+1$ on Rasch test scores by Students' Age Group. Notes: see notes in Figure 2.

\subsection{Robustness Checks}

4.2.1 Does the Proportion of Youngest Students in Advance in the Classroom Really Affect Scores?

To check the reliability of our findings, wefirst make an empirical exercise by simulating changes in the threshold of cutoff birth date for first enrollment at school. Specifically, we hypothesize a change in the cutoff for the 2nd grade only, keeping fixed the threshold for the 5th grade (August of year $t$ ). In this way, we can check the robustness of our previous results, that is: i) the proportion of youngest students "in advance" in the classroom really affects individual scores; ii) there is no selection in classroom formation.

First, we move the cutoff of the 2 nd grade from December of year $t$ to February of year $t+1$. In this simulation, pupils in advance at the 2nd grade are those who turn six either in March or in April of year $t+1$. Students in advance for the 5th grade are instead those who turn six between September of year $t$ and April of year $t+1$. Hence, pupils in advance for both grades are thosewho turn six in March or April $t+1$. In case of no sorting in classroom formation, the proportion of students attending the 5 th grade who turn six between September $t$ and February $t+1$ should give a not statistically significant parameter. 
Then, we consider that the cutoff for the 2 nd grade is in October of year t. Pupils in advance at the 2nd grade are those who turn six between November $t$ and April $t+1$ while pupils anticipating school entry for the 5 th grade remain those who turn six between September $t$ and April $t+1$. Thus, pupils in advance for both grades are those who turn six between November $t$ and April $t+1$. Information about Selection Effect can be gathered from the significance of the coefficient associated to the parameter representing students who turn six between September and October of year t. According to our identification strategy and to our previous findings we expect that this parameter is not statistically significant.

Results from simulations on Normalized and Rasch test scores are reported in Table 7 and 8 respectively. We can validate previous findings concerning the absence of selection in classroom formation. Coefficients related to Selection Effect are, in fact, not statistically significant changing the threshold of limit birth date for first enrollment at school.

Table 7. Classroom Peer Age Effect: Simulations on Normalized Test Scores

\begin{tabular}{|c|c|c|c|}
\hline \multirow[b]{3}{*}{ INDIVIDUAL AGE } & \multicolumn{3}{|c|}{ Reading } \\
\hline & Simulation 1 & Basic Estimates & Simulation 2 \\
\hline & & & \\
\hline Student's Age at school entry (in months) & $0.240 * * *$ & $0.240 * * *$ & $0.238 * * *$ \\
\hline \multicolumn{4}{|l|}{ CLASSROOM PEER AGE COMPOSITION } \\
\hline Proportion of students "in advance" & $13.137 * * *$ & $7.584 * * *$ & $2.287 * * *$ \\
\hline Selection Effect & 0.382 & 2.058 & 1.064 \\
\hline \multirow[t]{3}{*}{ Number of Obs } & 582,813 & 582,813 & 582,813 \\
\hline & \multicolumn{3}{|c|}{ Mathematics } \\
\hline & Simulation 1 & Basic Estimates & Simulation 2 \\
\hline INDIVIDUAL AGE & & & \\
\hline Student's Age at school entry (in months) & $0.346 * * *$ & $0.345 * * *$ & $0.343 * * *$ \\
\hline CLASSROOM PEER AGE COMPOSITION & & & \\
\hline Proportion of students "in advance" & $18.061 * * *$ & $8.999 * * *$ & $1.976 * * *$ \\
\hline Selection Effect & 2.950 & 4.096 & 4.017 \\
\hline Number of Obs & 583,615 & 583,615 & 583,615 \\
\hline
\end{tabular}

Notes: 1) Proportion of students "in advance" refers to those "in advance" for both the 2 nd and the 5 th Grade, i.e. to students who turn six in March or April $t+1$ in Simulation 1, pupils who turn six between January $t+1$ and April $t+1$ (Basic Estimates) and students who turn six between November $t$ and April $t+1$ in Simulation 2. 2) * $p<0.1 ; * * p<0.05$; $* * * p<0.01 .3)$ Coefficients are estimated with robust standard errors. 4) Estimates include student-level (individual characteristics and parents' background), school-level, geographic-level and other classroom peer age composition covariates; see Table 2 for details.

Table 8. Classroom Peer Age Effect: Simulations on Rasch Test Scores

\begin{tabular}{|c|c|c|c|}
\hline & \multicolumn{3}{|c|}{ Reading } \\
\hline & Simulation 1 & Basic Estimates & Simulation 2 \\
\hline $\begin{array}{l}\text { INDIVIDUAL AGE } \\
\text { Student's Age at school entry (in months) } \\
\text { CLASSROOM PEER AGE COMPOSITION }\end{array}$ & $0.016 * * *$ & $0.016 * * *$ & $0.016 * * *$ \\
\hline Proportion of students "in advance" & $0.739 * * *$ & $0.443 * * *$ & $0.126^{* * *}$ \\
\hline Selection Effect & 0.072 & 0.164 & 0.088 \\
\hline \multirow[t]{3}{*}{ Number of Obs } & 582,813 & 582,813 & 582,813 \\
\hline & \multicolumn{3}{|c|}{ Mathematics } \\
\hline & Simulation 1 & Basic Estimates & Simulation 2 \\
\hline $\begin{array}{l}\text { INDIVIDUAL AGE } \\
\text { Student's Age at school entry (in months) } \\
\text { CLASSROOM PEER AGE COMPOSITION }\end{array}$ & $0.020 * * *$ & $0.020 * * *$ & $0.019 * * *$ \\
\hline Proportion of students "in advance" & $1.361 * * *$ & $0.700 * * *$ & $0.181 * * *$ \\
\hline Selection Effect & 0.219 & 0.367 & 0.295 \\
\hline Number of Obs & 583,615 & 583,615 & 583,615 \\
\hline
\end{tabular}

Notes: see notes in Table 7.

\subsubsection{Is Selection Effect Invalidated by Parents' Perception of Wrong Cutoff Date?}

A key concern arises at this stage since a misperception of the real age threshold for school entry may be at work. Consider the enrollment rule at 1 st grade for pupils attending the 5th grade in 2012/2013. It imposes enrollment to children who will be aged 6 by August 31st of year t, allowing for optional enrollment to pupils who turn six from September $t$ until April $t+1$. As school starts in September of year $t$, parents' decisions to enroll their children at school couldnot take into account differences in cutoff date between mandatory and optional enrollment. This is to say that 
parents, independently from rules, could send their offspring to school if they turnsix by December of year t, considering as students "in advance" only those who turn six in year $t+1$. In the presence of misperception of cutoff date for mandatory school our strategy targeted to the evaluation of a Selection Effect would be invalidated since systematic assignment of children to classroom could take place only for those actually considered in "advance", i.e., those who turn six in year $t+1$.

Looking at descriptive statistics of months and year of birth of students attending the 2nd and the 5th grade of primary schools (Table 9), we can note there is a considerable number of pupils who turn six between September and December of year $\mathrm{t}$ in both grades, although for the 2 nd grade students who turn six in these months are "regular" while for the 5 th grade pupils who turn six in the last four months of year $t$ are "in advance". This could imply that parents feel cutoff date for mandatory enrollment as "wrong" and enroll their children as if they were regular although the law defines them "in advance". Frequencies of students enrolled at school in year t reduce when pupils are who turn six in year $t+1$. This seems to confirm that parents have the perception that their children are in advance only if they turn six in year $\mathrm{t}+1$.

Starting from these relevant considerations, in this Section we provide further empirical evidence to confirm there is no systematic assignment of students to classroom by age at school entry - and, hence, that the peer age effect we find is an unbiased effect - by employing an alternative identification strategy.

We focus on pupils attending the 8th grade - i.e. last year of lower secondary education - in 2012/2013 merging data with those of pupils attending the 2 nd grade in the same scholastic year and we exploit once again the different enrollment rules for 1st grade. As already said in Section 3.1, cutoff date for mandatory schooling for students attending the 2nd grade is December 31st of year t. Limit birth date for optional enrollment is April 30th of year $t+1$. For pupils attending the 8th grade, instead, cutoff date is fixed on August 31st while limit birth date for optional enrollment is March 31st of year $t+1$ (Note 4). Although students attending the 8th grade who turn six between September and December of year $t$ are students in advance for the 8th grade only, also in this case some doubts on the presence of cutoff misperception can arise (see Table 9).

To tackle the issue we focus our attention to those who turn six in year $t+1$ since only these pupils may be truly considered in advance. By comparing students who turn six in $t+1$ we can obtain an evaluation of the peer effect of arising from one month difference in age of early enrollees. Even if Selection Effect may be present, selection rules should be common to for both groups so that differences in peer age effect may only be related to variation in average age. Results from Table 10 confirm the absence of a peer age effect apart from any systematic assignment of early enrollees in Italian first cycle of education (Note 5) being the parameter of interaction variable Grade $8 *$ Proportion of students who turn six between $\mathrm{Jan}_{\mathrm{t}+1}-\mathrm{Mar}_{\mathrm{t}+1}$ negative and statistically significant. This finding corroborates the idea that there is a positive impact on individual performance of sharing the classroom with youngest pupils in advance.

Table 9. Frequencies of students by month and year of birth

\begin{tabular}{lcccccc}
\hline & \multicolumn{2}{c}{ Grade 2 } & \multicolumn{2}{c}{ Grade 5 } & \multicolumn{2}{c}{ Grade 8} \\
\cline { 2 - 7 } Month and year of birth & Reading & Mathematics & Reading & Mathematics & Reading & Mathematics \\
\hline January $_{\mathrm{t}}$ & 21,637 & 21,764 & 20,438 & 20,553 & 20,052 & 20,053 \\
February $_{\mathrm{t}}$ & 26,137 & 26,253 & 23,291 & 23,355 & 22,908 & 22,909 \\
March $_{\mathrm{t}}$ & 34,125 & 34,327 & 30,663 & 30,711 & 34,194 & 34,194 \\
April $_{\mathrm{t}}$ & 35,006 & 35,214 & 33,325 & 33,549 & 33,260 & 33,263 \\
May $_{\mathrm{t}}$ & 42,778 & 42,890 & 39,900 & 39,881 & 36,993 & 36,993 \\
June $_{\mathrm{t}}$ & 39,889 & 39,987 & 38,342 & 38,433 & 37,794 & 37,794 \\
July $_{\mathrm{t}}$ & 42,377 & 42,471 & 41,195 & 41,333 & 42,236 & 42,237 \\
August $_{\mathrm{t}}$ & 40,983 & 41,152 & 39,930 & 40,039 & 39,843 & 39,842 \\
September $_{\mathrm{t}}$ & 42,621 & 42,791 & 42,104 & 42,125 & 40,866 & 40,867 \\
October $_{\mathrm{t}}$ & 41,980 & 42,192 & 41,397 & 41,546 & 37,875 & 37,878 \\
November $_{\mathrm{t}}$ & 38,167 & 38,362 & 36,190 & 36,303 & 34,443 & 34,446 \\
December $_{\mathrm{t}}$ & 39,440 & 39,594 & 36,506 & 36,623 & 35,322 & 35,325 \\
January $_{\mathrm{t}+1}$ & 19,374 & 19,370 & 18,921 & 18,966 & 19,830 & 19,830 \\
February $_{\mathrm{t}+1}$ & 9,291 & 9,304 & 11,622 & 11,598 & 12,050 & 12,049 \\
March $_{\mathrm{t}+1}$ & 6,499 & 6,466 & 7,240 & 7,220 & 8,718 & 8,718 \\
April $_{\mathrm{t}+1}$ & 4,295 & 4,325 & 4,631 & 4,604 & - & - \\
\hline
\end{tabular}

Notes: 1) Cutoff date for first enrolment is August 31st of year t for students attending both the 5th and 8th Grade in 2012/2013 while is December 31st of year t for those attending the 2nd Grade in the same year. 2) Limit birth date for optional enrolment is April 30th of year $t+1$ for pupils attending both the 2nd and the 5th Grade while is March 31 st of year $\mathrm{t}+1$ for those attending the 8 th Grade in 2012/2013. 
Table 10. Classroom Peer Age Effect on Normalized Test Scores and Identification of Selection Effect: 2nd and 8th Grade

\section{CLASSROOM PEER AGE COMPOSITION}

Proportion of delayed students

Proportion of students who turn six between $\mathrm{Jan}_{\mathrm{t}}-\mathrm{Apr}_{\mathrm{t}}$

Proportion of students who turn six between $\mathrm{Sept}_{\mathrm{t}}-\mathrm{Dec}_{\mathrm{t}}$

Proportion of students who turn six between $\mathrm{Jan}_{\mathrm{t}+1}-\mathrm{Apr}_{\mathrm{t}+1}$

Grade $8 *$ Proportion of delayed students

Grade $8 *$ Proportion of students who turn six between $\operatorname{Jan}_{\mathrm{t}}-\mathrm{Apr}_{\mathrm{t}}$

Grade 8*Proportion of students who turn six between May $_{t}-$ Aug $_{t}$

Grade 8*Proportion of students who turn six between Sept $_{\mathrm{t}}-\mathrm{Dec}_{\mathrm{t}}$

Grade $8 *$ Proportion of students who turn six between $\mathrm{Jan}_{\mathrm{t}+1}-\mathrm{Mar}_{\mathrm{t}+1}$ Number of Obs

\begin{tabular}{cc} 
Reading & Mathematics \\
\hline & \\
$-5.518 * * *$ & $-7.857 * * *$ \\
-0.017 & -0.176 \\
$-1.833 * * *$ & $-3.488 * * *$ \\
$5.960 * * *$ & $8.096 * * *$ \\
3.294 & $8.533 * *$ \\
$10.052 * * *$ & $15.336 * * *$ \\
$8.488^{* * *}$ & $11.344 * * *$ \\
$8.666 * * *$ & $14.052 * * *$ \\
$-1.826 *$ & $-2.702 *$ \\
\hline 557,734 & 558,058
\end{tabular}

Notes: 1) * $\mathrm{p}<0.1 ; * * \mathrm{p}<0.05$; *** $\mathrm{p}<0.01 .2)$ Coefficients are estimated with robust standard errors. 3) Estimates include student-level (individual characteristics and parents' background), school-level and geographic-level covariates; see Table 2 for details.

\subsubsection{Does “Cheating” Bias Results?}

INVALSI tries to ensure the correctness of tests by "sending" external supervisors in some sampled schools. In these schools do not emerge incorrect behaviors (see INVALSI Report, 2013). Moreover, in the last few years, INVALSI has realized, in partnership with MIUR (Ministry of Education, Universities and Research), an intensive formation/information campaign in some regions of South Italy - Campania, Puglia, Calabria and Sicilia - where the cheating phenomenon is more relevant. In this Section we would like to check if our previous findings are biased by incorrect behavior providing additional evidence by using scores revised for "cheating". INVALSI datasets, in fact, contain for year 2012/2013 a correction factor (Note 6) allowing to compute scores correct for the presence of cheating.

Table 11. Classroom Peer Age Effect on Rasch Test Scores Revised for "Cheating” and Identification of Selection Effect: 2nd and 5th Grade

\section{CLASSROOM PEER AGE COMPOSITION}

Proportion of delayed students

Proportion of students who turn six between $\mathrm{Jan}_{\mathrm{t}}-\mathrm{Apr}_{\mathrm{t}}$

Proportion of students who turn six between $\operatorname{Sept}_{\mathrm{t}}-\mathrm{Dec}_{\mathrm{t}}$

Proportion of students who turn six between $\operatorname{Jan}_{t+1}-\mathrm{Apr}_{\mathrm{t}+1}$

Grade $5 *$ Proportion of delayed students

Grade $5 *$ Proportion of students who turn six between $\operatorname{Jan}_{\mathrm{t}}-\mathrm{Apr}_{\mathrm{t}}$

Grade $5 *$ Proportion of students who turn six between $\mathrm{May}_{\mathrm{t}}-\mathrm{Aug}_{\mathrm{t}}$

Grade $5 *$ Proportion of students who turn six between Sept $_{t}-$ Dec $_{t}$

Number of Obs

\begin{tabular}{cc} 
Reading & Mathematics \\
\hline & \\
$-0.385^{* * *}$ & $-0.562^{* * *}$ \\
$-0.055^{* * *}$ & $-0.039^{*}$ \\
$-0.046^{* * *}$ & $-0.123^{* * *}$ \\
$0.291^{* * *}$ & $0.373^{* * *}$ \\
-0.119 & $0.319^{*}$ \\
0.210 & $0.405^{* *}$ \\
0.049 & 0.199 \\
0.041 & 0.277 \\
\hline 582,813 & 583,615 \\
\hline
\end{tabular}

Notes: 1) * $\mathrm{p}<0.1$; ** $\mathrm{p}<0.05$; *** $\mathrm{p}<0.01 .2)$ Coefficients are estimated with robust standard errors. 3) Estimates include student-level (individual characteristics and parents' background), school-level and geographic-level covariates; see Table 2 for details.

Table 12. Classroom Peer Age Effect on Rasch Test Scores Revised for "Cheating" and Identification of Selection Effect: 2nd and 8th Grade

\section{CLASSROOM PEER AGE COMPOSITION}

Proportion of delayed students

Proportion of students who turn six between $\mathrm{Jan}_{\mathrm{t}}-\mathrm{Apr}_{\mathrm{t}}$

Proportion of students who turn six between $\operatorname{Sept}_{t}-\mathrm{Dec}_{\mathrm{t}}$

Proportion of students who turn six between $\mathrm{Jan}_{\mathrm{t}+1}-\mathrm{Apr}_{\mathrm{t}+1}$

Grade $8 *$ Proportion of delayed students

Grade $8 *$ Proportion of students who turn six between $\mathrm{Jan}_{\mathrm{t}}-\mathrm{Apr}_{\mathrm{t}}$

Grade $8 *$ Proportion of students who turn six between May $\mathrm{y}_{\mathrm{t}}-\mathrm{Aug}_{\mathrm{t}}$

Grade 8*Proportion of students who turn six between Sept $_{\mathrm{t}}-$ Dec $_{\mathrm{t}}$

Grade $8 *$ Proportion of students who turn six between $\mathrm{Jan}_{\mathrm{t}+1}-\mathrm{Mar}_{\mathrm{t}+1}$

Number of Obs

Notes: see notes in Table 11. 
Table 13. Classroom Peer Age Effect on Rasch Test Scores Revised for “Cheating” by Students' Age Group

\begin{tabular}{|c|c|c|c|c|}
\hline & \multicolumn{4}{|c|}{ Reading } \\
\hline & $\begin{array}{c}65 \leq \text { Age } \leq 68 \\
\text { (Students who } \\
\text { turn six between } \\
\mathrm{Jan}_{\mathrm{t}+1}-\mathrm{Apr}_{\mathrm{t}+1} \text { ) }\end{array}$ & $\begin{array}{c}69 \leq \text { Age } \leq 72 \\
\text { (Students who } \\
\text { turn six between } \\
\text { Sept }_{t}-\text { Dec }_{t} \text { ) }\end{array}$ & $\begin{array}{c}73 \leq \text { Age } \leq 76 \\
\text { (Students who } \\
\text { turn six between } \\
\text { May }_{\mathrm{t}}-\text { Aug }_{\mathrm{t}} \text { ) }\end{array}$ & $\begin{array}{c}77 \leq \text { Age } \leq 80 \\
\text { (Students who } \\
\text { turn six between } \\
\text { Jan }_{\mathrm{t}}-\mathrm{Apr}_{\mathrm{t}} \text { ) } \\
\end{array}$ \\
\hline $\begin{array}{l}\text { CLASSROOM PEER AGE COMPOSITION } \\
\text { Proportion of students who turn six between } \mathrm{Jan}_{\mathrm{t}+1}-\mathrm{Apr}_{\mathrm{t}+1}\end{array}$ & $0.396 * * *$ & $0.389 * * *$ & $0.315 * * *$ & $0.231 * * *$ \\
\hline \multirow[t]{3}{*}{ Number of Obs } & 47,078 & 191,035 & 195,848 & 138,286 \\
\hline & \multicolumn{4}{|c|}{ Mathematics } \\
\hline & $\begin{array}{c}65 \leq \text { Age } \leq 68 \\
\text { (Students who } \\
\text { turn six between } \\
\left.\operatorname{Jan}_{\mathrm{t}+1}-\mathrm{Apr}_{\mathrm{t}+1}\right)\end{array}$ & $\begin{array}{c}69 \leq \text { Age } \leq 72 \\
\text { (Students who } \\
\text { turn six between } \\
\text { Sept }_{\mathrm{t}}-\mathrm{Dec}_{\mathrm{t}} \text { ) }\end{array}$ & $\begin{array}{c}73 \leq \text { Age } \leq 76 \\
\text { (Students who } \\
\text { turn six between } \\
\text { May }_{\mathrm{t}}-\text { Aug }_{\mathrm{t}} \text { ) }\end{array}$ & $\begin{array}{c}77 \leq \text { Age } \leq 80 \\
\text { (Students who } \\
\text { turn six between } \\
\text { Jan }_{\mathrm{t}}-\mathrm{Apr}_{\mathrm{t}} \text { ) } \\
\end{array}$ \\
\hline $\begin{array}{l}\text { CLASSROOM PEER AGE COMPOSITION } \\
\text { Proportion of students who turn six between } \mathrm{Jan}_{\mathrm{t}+1}-\mathrm{Apr}_{\mathrm{t}+1}\end{array}$ & $0.522 * * *$ & $0.482 * * *$ & $0.321 * * *$ & $0.221 * * *$ \\
\hline Number of Obs & 47,027 & 191,318 & 196,001 & 138,586 \\
\hline
\end{tabular}

Notes: 1) * $\mathrm{p}<0.1 ; * * \mathrm{p}<0.05 ; * * * \mathrm{p}<0.01$. 2) Coefficients are estimated with robust standard errors. 3) Estimates include student-level (individual characteristics and parents' background), school-level, geographic-level and other classroom peer age composition covariates; see Table 2 for details.

We present results of classroom peer age effect on Rasch test scores in Tables 11, 12 and 13. Specifically, in Table 11 we replicate results by using data on pupils attending both the 2 nd and the 5 th grade of primary school in Italy. Findings confirm the positive impact of the proportion of students in advance on individual educational outcomes. When we consider the alternative identification strategy, using data of students attending the 2nd and the 8th grade and replicating regressions on "revised" test scores, we obtain similar results of previous estimates (Table 12). Also in this case coefficients of the proportion of students in advance are positive and statistically significant at 1\% level. Finally, in Table 13 we report estimates of peer age effect on Rasch test scores by students' age group. The peer age effect shows a decreasing effect in pupil's' age also in this case.

\section{Concluding Remarks}

In their influential study, Coleman et al. (1966) assert that peer quality is one of the main factors that could influence student outcomes besides family background. Since then, empirical evidence has been put forward to demonstrate that the quality of student's schoolmates is an important determinant of academic performance and, by extension, of other life outcomes.

If students are affected by characteristics of their schoolmates, that is if peer effect exists in education, then the school system that encourages an efficient distribution of peers will make human capital investments more efficient and it will increase economic growth. So, understanding the nature and importance of peer group effects in education becomes crucial for education policy.

Identifying and estimating peer effects raises some challenges. The main issue is that peer effects must be isolated from confounding factors. Especially, spurious correlation between students' outcomes may arise from selection into groups and from common unobserved shocks. Spurious correlated effects may be important if the allocation of teachers and students to classes is not random (class-level selection biases).

In this study we face selection bias by exploiting changes in Italian enrollment rule occurred in the recent past. Results do not appear to be influenced by selection issues so that systematic assignment of students and teachers to classrooms does not seem to take place and to be relevant in determining students' performance of Italian primary school pupils. Results are obtained employing the whole universe of pupils attending the Grades 2 and 5 of primary schools in Italy. Data cover all schools and all classrooms. Thus, through an identification strategy never used in previous studies, we show that in Italy peer age impact on academic performance may arise from a "true" spillover. Specifically, results suggest that the proportion of students "in advance" in the classroom has a positive effect on Normalized and Rasch test scores both in Reading and in Mathematics of classmates. All findings seem to be not invalidated by "cheating" phenomena.

The way through which the impact of the classmates' age interacts with individual performance remains an open issue. The positive impact on cognitive attainment could arise from ability spillover since students in advance may be those who are ready for school despite their young age. This effect could be enhanced by teachers' behavior consisting in easing the learning process, modifying curriculum choices and slowing down the pace of the lessons when in the presence of very young pupils. Further research should be devoted to understand how these channels contribute to the overall improvement of classroom in test scores. 


\section{References}

Ammermueller, A., \& Pischke, J. S. (2009). Peer effects in European primary schools: evidence from Pirls. Journal of Labor Economics, 27(3), 315-348. Retrieved from http://www.jstor.org/stable/10.1086/603650

Angrist, J. D., \& Lang, K. (2004). Does School Integration Generate Peer Effects? Evidence from Boston's Metco Program. The American Economic Review, 94(5), 1613-1634. http://dx.doi.org/10.1257/0002828043052169

Boucher, V., Bramoullé, Y., Djebbari, H., \& Fortin, B. (2010). Do peers affect student achievement? Evidence from Canada using group size variation, IZA Discussion Papers, 4723. http://dx.doi.org/10.2139/ssrn.1566956

Burke, M. A., \& Sass, T. R. (2013).Classroom Peer Effects and Student Achievement.Journal of Labor Economics, 31(1), 51-82. Retrieved from http://www.jstor.org/stable/10.1086/666653

Carman, K. G., \& Zhang, L. (2012). Classroom peer effects and academic achievement: Evidence from a Chinese middle school. China Economic Review, 23, 223-237. http://dx.doi.org/10.1016/j.chieco.2011.10.004

Coleman, J. S., Campbell, E. Q., Hobson, C. J., McPartlan, J., Mood, A. M., Weinfeld, F. D., \& York, R. L. (1966). Equality of Educational Opportunity, Washington, DC: Government Printing Office.

Elder, T. E., \& Lubotsky, D. H. (2009). Kindergarten Entrance Age and Children.s Achievement: Impacts of State Policies, Family Background, and Peers. Journal of Human Resources, 44(3), 641-683. http://dx.doi.org/10.1353/jhr.2009.0015

Hanushek, E. A., Kain, J. F., Markman, J. M., \& Rivkin, S. G. (2003). Does peer ability affect student achievement? Journal of Applied Econometrics, 18, 527-544. http://dx.doi.org/10.1002/jae.741

Ladd, G. W. (1990). Having Friends, Keeping Friends, Making Friends, and Being Liked by Peers in the Classroom: Predictors of Children's Early School Adjustment? Child Development, 61, 1081-1100. http://dx.doi.org/10.1111/j.1467-8624.1990.tb02843.x

Lavy, V., Silva, O., \& Weinhardt, F. (2009). The good, the bad and the average: evidence on the scale and nature of ability peer effects in schools, NBER Working Paper, 15600. Retrieved from http://www.nber.org/papers/w15600

Leuven, E., \& Rønning, M. (2011).Classroom grade composition and pupil achievement, IZA Discussion paper series, 5922. Retrieved from http://www.econstor.eu/handle/10419/55052

McEwan, P. J. (2003). Peer effects on student achievement: evidence from Chile. Economics of Education Review, 22, 131-141. http://dx.doi.org/10.1016/S0272-7757(02)00005-5

Ordine, P., Rose, G., \& Sposato, D. (2014). Gift of Time or Parents' Gift? The Effect of Early School Entry on Pupils Performance. Paper presented at the 29th Annual Congress of the European Economic Association, Toulouse, France. Retrieved from http://www.eea-esem.com/files/papers/EEA-ESEM/2014/2552/ORS_EEA.pdf

Ponzo, M., \& Scoppa, V. (2014). The long-lasting effects of school entry age: Evidence from Italian students. Journal of Policy Modeling, 36, 578-599. http://dx.doi.org/10.1016/j.jpolmod.2014.04.001

Rasch, G. (1960). Probabilistic models for some intelligence and attainment tests, Oxford, England: Nielsen \& Lydiche.

Sandgren, S., \& Strøm, B. (2005). Peer effects in primary school: Evidence from age variation. Paper presented at the 17th Annual congress of the European Economic Association, Venice, Italy. Retrieved from http://www.eea-esem.com/files/papers/EEA-ESEM/2006/999/Sandgren-Strom-EEA06.pdf

Stinebrickner, R., \& Stinebrickner, T. R. (2006). What can be learned about peer effects using college roommates? Evidence from new survey data and students from disadvantaged backgrounds. Journal of Public Economics, 90, 1435-1454. http://dx.doi.org/10.1016/j.jpubeco.2006.03.002

Vandenberghe, V. (2002). Evaluating the magnitude and the stakes of peer effects analysing science and math

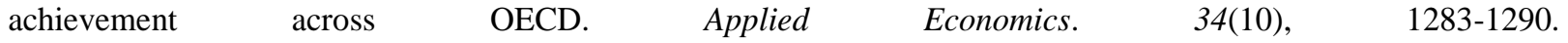
http://dx.doi.org/10.1080/00036840110094446

Zimmerman, D. J. (2003). Peer effects in academic outcomes: Evidence from a natural experiment. The Review of Economics and Statistics, 85(1), 9-23. http://dx.doi.org/10.1162/003465303762687677 


\section{Notes}

Note 1. See Circular of the Ministry of Education n.101/2010.

Note 2. See Circular of the Ministry of Education n.110/2007.

Note 3. INVALSI computes a correction factor. For details on computing procedure see Rapporto SNV PN 2013 at www.invalsi.it.

Note 4. See Circular of the Ministry of Education n.90/2004.

Note 5. Italian Education System is structured into preprimary education following by two education cycle: i) First cycle, divided in primary education and lower secondary education; ii) Second cycle, including upper secondary school and vocational training. As previous findings provide evidence there is not selection in primary school (2nd and 5th grade) and results of alternative identification strategy implemented in this section provide evidence of the absence of selection by age in lower secondary school too, we can affirm that, overall, systematic assignment of pupils to classes seems do not take place in the first cycle of education.

Note 6. For details on computing procedure see Rapporto SNV PN 2013 at www.invalsi.

\section{$(\mathrm{cc}) \mathbf{E Y}$}

This work is licensed under a Creative Commons Attribution 3.0 License. 